\title{
Edukasi Praktik Ecobrick Sebagai Sumber Belajar Anak Usia Dini di Desa Maitara Kota Tidore Kepulauan
}

\author{
Farida Samad $^{1 *}$, Rita Samad $^{2}$, Zulkifli Zam Zam ${ }^{3}$ \\ ${ }^{1 *, 2}$ PG-PAUD, FKIP, Universitas Khairun Ternate \\ ${ }^{3}$ Pendidikan Kimia, FKIP, Universitas Khairun Ternate \\ *Corresponding Author. Email: faridasamad81@gmail.com
}

\begin{abstract}
The purpose of this community service is to provide knowledge about managing plastic waste through Reduce, Reuse, and Recycle (3R). Ecobrick is one of the recycling efforts to minimize the amount of plastic waste movements, by providing knowledge and skills to PAUD Sukun teachers, South Maitara Village, Tidore Islands City in utilizing plastic waste as an educational learning medium. Respondents in this training as many as 20 people, using the lecture method, question and answer, demonstration and discussion. The results of the activity showed that the APE Ecobrick training had a significant impact on the participants, namely knowledge (knowledge) increased by $42.86 \%$, skills increased by $44.26 \%$ and ability (ability) became $44.29 \%$. This training is expected to help teachers to create creative and innovative APE using an environmental approach, as well as introduce students to the dangers of plastic waste to the environment, and shape their behavior to recognize and love the environment.
\end{abstract}

Abstrak: Tujuan pengabdian ini adalah untuk memberikan pengetahuan/pemahaman tentang mengelola sampah plastik yang dilakukan melalui Reduce, Reuse, dan Recycle (3R). Ecobrick merupakan salah satu upaya daur ulang (recycle) untuk meminimalisir jumlah sampah plastik melalui gerakan masyarakat, dengan memberikan pengetahuan dan keterampilan kepada para guru PAUD Sukun Desa Maitara Selatan Kota Tidore Kepulauan dalam memanfaatkan sampah platik sebagai media pembelajaran edukatif. Responden pada pelatihan ini sebanyak 20 orang, menggunakan metode ceramah, tanya jawab, demonstrasi dan diskusi. Hasil kegiatan menunjukkan bahwa pelatihan APE Ecobreak sangat berdampak terhadap peserta, yakni pengetahuan (knowledge) meningkat 42,86\%, ketrampilam (skill) naik 44,26\% dan kemampuan (ability) menjadi 44,29\%. Pelatihan ini diharapkan dapat membantu para guru untuk membuat APE yang kreatif dan inovatif dengan menggunakan environmental approach, sekaligus memperkenalkan kepada anak didik tentang bahaya sampah plastic terhadap lingkungan, serta membentuk perilakunya untuk mengenal dan mencintai lingkungan.

\section{Article History:}

Received: 20-09-2021

Reviewed: 02-10-2021

Accepted: 14-10-2021

Published: 13-11-2021

Key Words:

Education,

Ecobrick, Learning

Resources, Early

Childhood.

\section{Sejarah Artikel:}

Diterima: 20-09-2021

Direview: 02-10-2021

Disetujui: 14-10-2021

Diterbitkan: 13-11-2021

\section{Kata Kunci:}

Edukasi,

Ecobrick, Sumber

Belajar, Anak Usia Dini

How to Cite: Samad, F., Samad, R., \& Zam Zam, Z. (2021). Edukasi Praktik Ecobrick Sebagai Sumber Belajar Anak Usia Dini di Desa Maitara Kota Tidore Kepulauan. Jurnal Pengabdian UNDIKMA, 2(2), 125-133. doi:https://doi.org/10.33394/jpu.v2i2.4165

https://doi.org/10.33394/jpu.v2i2.4165

This is an open-access article under the CC-BY-SA License.

\section{Pendahuluan}

Saat ini sampah merupakan suatu fenomena yang kerap ditemukan di lingkungan masyarakat dan sudah menjadi hal lumrah., keberadaannya sangat mengganggu kesehatan masyarakat sekitar. Sampah adalah sisa kegiatan sehari-hari manusia dan proses alam yang berbentuk padat (UU No.18 Tahun 2018 tentang Pengelolaan Sampah). Sampah spesifik adalah sampah yang karena sifat, konsentrasi, dan/atau volumenya memerlukan pengelolaan 
khusus. Sampah adalah sesuatu yang tidak digunakan, tidak dipakai, tidak disenangi atau sesuatu yang dibuang yang berasal dari kegiatan manusia dan tidak terjadi dengan sendirinya (Ela Patriana \& Nurismalatri, 2008). Saat ini masalah sampah menjadi masalah yang sulit ditangani di kota-kota yang ada di Indonesia terutama di Kota Ternate. Ternate menghasilkan sampah mencapai \pm 300 ton/hari untuk ditampung ke Tempat Pembuangan Akhir (Akbar et al., 2014).

Maluku Utara khususnya Kota Tidore Kepulauan merupakan salah satu penghasil sampah plastik yang ada di perairan dan mengukuhkan Indonesia sebagai penyumbang sampah plastik di laut. Palupi et al., (2020) menjelaskan bahwa pada 2015, Jambeck Research Group merilis laporan penelitian "Plastic waste inputs from land into the ocean" di 192 negara. Dalam laporan tersebut memuat peringkat 192 negara berdasarkan perkiraan sampah plastik yang tidak terkelola dengan baik pada 2010. Indonesia turut menyumbang sampah plastik di laut sebesar 1, 3 juta ton per tahun, berada di peringkat kedua setelah Tiongkok sebesar 3, 5 juta ton per tahun. Lebih lanjut, sampah plastik yang tidak terkelola (mismanaged plastic waste) di Indonesia sebesar 3,22 juta ton per tahun, di bawah Tiongkok sebesar 8,82 juta ton sampah plastik per tahun. Tentu saja diperkirakan pada tahun 2025, sampah plastik di Indonesia yang tidak terkelola sebesar 7, 4 juta ton per tahun .

Permasalahan sampah plastik di Kota Ternate yang makin meningkat tentu saja menimbulkan dampak buruk di masyarakat. Padahal pemerintah Kota Ternate telah memiliki Peraturan Daerah tentang Pengelolaan Sampah. Menurut Fitriani \& Asih (2019) dan Adnyani et al., (2019), timbulan plastik hanya 10-15\% saja yang telah didaur ulang, 60-70\% ditimbun di tempat pembuangan akhir, dan 15-30\% belum terkelola sampai terbuang ke lingkungan terutama perairan seperti sungai, danau, pantai, dan laut. Sampah plastik pada umumnya sulit untuk didegradasi dan menyebabkan pencemaran terhadap lingkungan. Plastik adalah sampah yang sulit diuraikan dalam kurun waktu 1000 tahun. Belum lagi pemusnahan plastik dengan cara dibakar juga akan menimbulkan permasalahan lain, seperti pencemaran udara. Untuk itu, berbagai upaya dilakukan guna mengelola sampah plastik tersebut dan hal ini dapat dilakukan melalui Reduce, Reuse, dan Recycle (3R).

Salah satu upaya daur ulang (recycle) yang digunakan untuk meminimalisir jumlah sampah plastik dan solusi limbah lokal dilakukan oleh gerakan masyarakat yang berkembang di seluruh dunia yaitu ecobrick. Ecobrick adalah botol plastik yang diisi padat dengan limbah non-biological (bahan-bahan seperti tanah, busa, plastik pembungkus makanan, kantong plastik, serta bahan-bahan plastik lainnya ) untuk membuat blok bangunan yang dapat digunakan kembali. Ecobrick atau disebut juga eko-batu bata adalah teknologi berbasis kolaborasi yang menyediakan solusi limbah padat tanpa biaya untuk individu, rumah tangga, sekolah, dan masyarakat, yang dikenal juga sebagai bottle brick atau ecoladrillo.

Ecobrick bertujuan untuk mengurangi sampah plastik dan mendaur ulang dengan media botol plastik untuk dijadikan sesuatu yang berguna. Ecobrick biasanya terbuat dari botol plastik bekas yang diisi dengan plastik-plastik lain yang berukuran lebih kecil. Kamble dan Karad juga menjelaskan bahwa ecobrick dimanfaatkan sebagai bahan bangunan. Ecobrick dapat digunakan untuk membuat furniture, taman dan bangunan dalam skala besar antara lain sekolah dan rumah. Ecobrick juga dapat digunakan untuk membuat karya seni antara lain pembuatan meja, kursi, tembok, maupun barang kesenian lainnya. Ternyata metode ini cukup terbukti mengurangi jumlah plastik di Kanada, negara tempat bernaung pencipta ecobrick, yaitu Russell Maier. Karya seni ini mengusulkan konsep daur ulang dan ide-ide baru dalam membuat batu bata ramah lingkungan (ecobrick) (Pujiati, 2019)(Andriastuti et al., 2019)(Aulina et al., 2018) (Chandra, 2020). 
Setiap orang dalam sebuah komunitas dapat bergabung membuat ecobrick termasuk anak-anak. Pembuatan ecobrick juga memungkinkan kolaborasi antara siswa, orang tua, guru dan staff di sekolah dalam menciptakan ruang hijau yang indah tanpa biaya yang mahal, seperti taman bermain dan taman. Kegiatan pembuatan ecobrick dapat juga dimasukkan ke dalam kurikulum (Maier \& Angway dalam Istirokhatun \& Nugraha, 2019). Dengan demikian, diperlukan suatu solusi sebagai upaya konkret yang dapat dilakukan, salah satunya adalah pendampingan bagi lembaga PAUD yang ingin mengembangkan pengetahuan serta keterampilan guru-guru dalam memanfaatkan ecobrick sebagai media pembelajaran khususnya sebagai bahan dasar pembuatan alat permainan edukatif (APE) sehingga diharapkan para guru setiap mengajar dapat mempersiapkan APE sendiri dengan memanfatkan barang-barang yang ada di sekitar anak dan dapat menentukan media yang sesuai dengan tema pembelajaran.

Sasaran dari kegiatan pengabdian ini adalah lembaga PAUD Sukun Desa Maitara Selatan Kota Tidore Kepulauan dengan melibatkan secara aktif guru kelompok A dan kelompok B dengan tujuan memperkenalkan dan meningkatkan pengetahuan serta keterampilan tentang ecobrick sebagai sumber belajar khususnya bahan dasar dalam pembuatan Alat Permainan Edukatif (APE) bagi anak dalam rangka merangsang perkembangan fisik motorik halus anak, sosioemosional, kreativitas, seni, dan dapat digunakan untuk merangsang perkembangan kognitif anak di sekolah.

Kegiatan PKM ini dilaksanakan karena beberapa kondisi yang menunjukkan rendahnya pengetahuan dan kreativitas guru PAUD tentang pemanfataan sampah plastik sebagai media pembelajaran yang ramah lingkungan, kurangnya stimulasi guru terhadap anak-anak tentang karakter mencintai lingkungan, dan tentu saja jumlah sampah plastik yang belum dimanfaatkan secara optimal. Tentu saja berbagai upaya untuk mengatasi permasalah telah dilakukan, antara lain dengan memanfaatkan sampah plastik untuk membuat kerajinan tangan seperti bunga, tas, baju, dan sebagainya, akan tetapi upaya yang dilakukan tersebut masih belum optimal dalam mengurangi jumlah sampah plastik yang ada. Oleh karena itu, perlu upaya lain untuk mengatasi masalah sampah tersebut. Berdasarkan kondisi tersebut di atas, maka solusi yang ditawarkan adalah memberikan pengetahuan dan melatih kreativitas guru PAUD Sukun Desa Maitara Selatan Kota Tidore Kepulauan tentang ecobrick sebagai sumber belajar khususnya bahan dasar dalam pembuatan Alat Permainan Edukatif (APE) bagi anak usia dini.

\section{Metode Pengabdian}

Program kegiatan PKM ini adalah program pendampingan yang berupa pelatihan untuk meningkatkan kompetensi guru di lembaga PAUD Desa Maitara Selatan Kecamatan Tidore Utara, Kota Tidore Kepulauan Kepulauan dalam merancang dan mengembangkan secara khusus untuk kepentingan pembelajaran bagi anak usia dini. Khalayak sasaran dalam kegiatan pengabdian ini adalah guru PAUD Sukun Kecamatan Tidore Utara, Kota Tidore Kepulauan yang diprioritaskan untuk 20 orang dengan alasan bahwa peserta yang dipilih memiliki guru pada tempat penyelenggaraan.

Metode yang digunakan dalam pengabdian ini yakni; metode ceramah, demonstrasi, praktek langsung, tanya jawab dan evaluasi. Metode ceramah dilakukan melalui pemberian materi atau informasi secara teoritik terkait dengan ecobrik, bahaya dan manfaat sampah plastic, dan ecobrik sebagai sumber belajar AUD. Demonstrasi dilakukan untuk memberi pengetahuan sekaligus menciptakan berbagai bentuk karya berbahan dasar sampah plastic sekaligus menyiapkan peralatan yang akan digunakan dalam kegiatan bermain dengan 
menggunakan ecobrick. Praktek bertujuan untuk memberikan pengetahuan dan pengalaman secara langsung kepada peserta untuk berkerasi dalam mebuat APE berbasis ecobrick. Tanya jawab, dilakukan untuk memecahkan berbagai permasalahan yang dihadapi peserta dalam merancang ecobrick. Evaluasi dilakukan dengan menggunakan statistic sederhana untuk untuk mengetahui tingkat pengetahuan (knowledge), keterampilan (skill) dan kemampuan (ability) peserta pada kegiatan tersebut.

\section{Hasil Pengabdian dan Pembahasan}

Berdasarkan hasil pelaksanaan pelatihan/pengabdian yang dilakukan di PAUD Sukun Desa Maitara Selatan Kecamatan Tidore Utara Kota Tidore Kepulauan, tahapan pelaksanaan kegiatan sebagai berikut;

$\checkmark$ Sesi Permata: Pemaparan materi umum tentang APE ecobrick disampaikan oleh ibu Rita Samad, M.Pd.Si. dan Dr. Zulkifli Zam Zam, M.Sc.dengan waktunya kurang lebih 60 menit. dan sharing. Pada materi ini kedua penyaji menyampaikan tentang konsep ecobreak, pentingnya APE untuk anak-anak PAUD, serta bahaya sampah plastic

$\checkmark$ Sesi kedua: Untuk proses pembuatan ecobrick yang disampaikan oleh Farida Samad, M.KPd, selama kurang lebih 150 menit dan selanjutnya dilakukan demo pembuatan ecobrick.

Untuk tahapan kegiatan praktek para peserta diberi pengetahuan dan ketrampilan untuk membuat alat permainan edukatif untuk guru dan siswa, diantaranya membentuk boneka penguin dari botol bekas air mineral, membuat pesawat terbang, bunga, pot bunga, dan lain sebagainya. Point penting dari pelaksanaan kegiatan adalah para peserta harus diberi pengetahuan untuk meningkatkan kreatifitas dan inovasi yang dimiliki utamanya memanfaatkan limbah/ sampah plastic yang sangat mengancam masa depan bumi menjadi bahan edukasi.

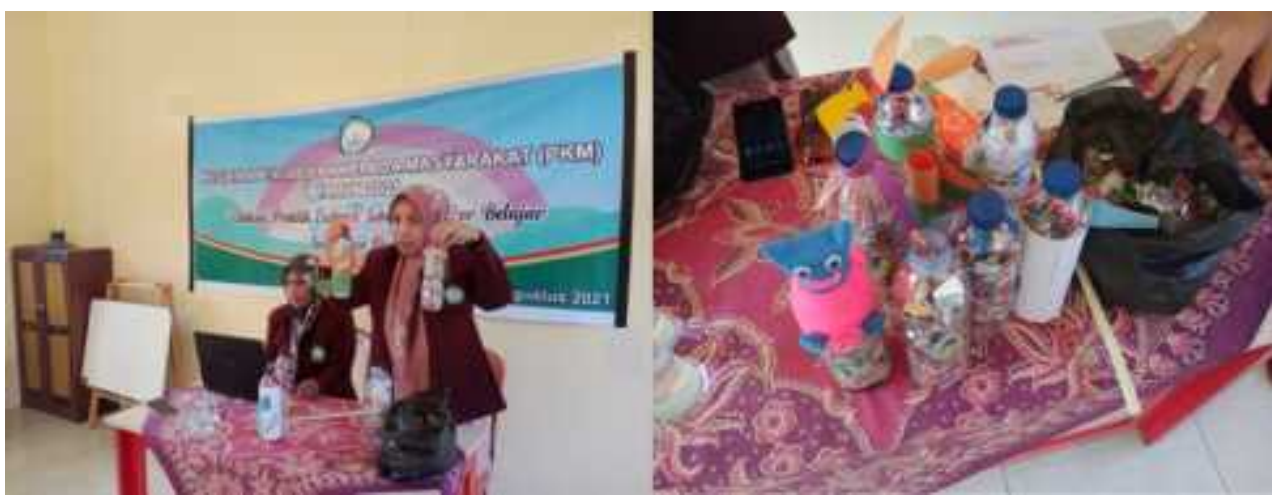

Gambar 2. Demo dan Eksperimen Pembuatan APE Ecobreak

Setelah pemaparan materi, demo pembuatan APE dan sharing/ tanya jawab terkait dengan cara pembuatan APE ecobrick, tahapan selanjutnya adalah memberikan kesempatan kepada para peserta untuk membuat APE dengan memanfaatkan sampah plastic berbagai ukuran. Sampah plastic yang digunakan adalah sampah plastic yang dikumpulkan di warungwarung dekat tempat pelatihan, dimana pada saat pengumpulan tersebut peserta diberi penjelasan bahwa sampah platik yang berupa botol bekas air minum seperti ini pasti banyak. Terbukti saat ini yang kita butuhkan untuk eksperimen membuat APE ecobrick tidak ada kesulitan, bahkan cukup mencarinya di lingkungan tempat kegiatan. Artinya bahwa bahan seperti ini cukuplah banyak dan disekitar kita, dan boleh tanpa disadari jadi kita juga menjadi bagian dari adanya sampah platik tersebut. 


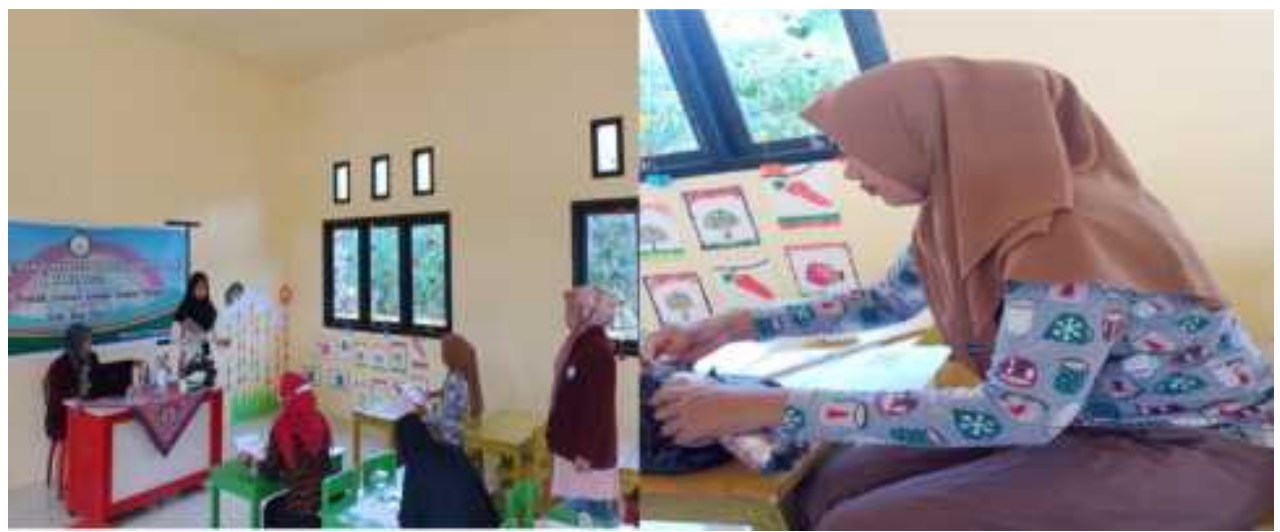

Gambar 3. Praktek Pembuatan APE Ecobrick

Penjelasan ini tentunya menggugah pikiran para peserta bahwa sampah plastic adalah ancaman dan masalah bersama ummat manusia di bumi, tidak terkecuali. Sehingga memberikan pengetahuan sedini mungkin kepada peserta disik termasuk anak-anak PAUD sangatlah penting, terutama terkait dengan bahaya sampah plastik tersebut. Jika pesan ini bisa diteruskan hingga ke siswa, nantinya diharapkan para siswa atau peserta didik memiliki perilaku menjaga lingkungan. Karena anak pada usia 2-6 tahun adalah usia praoperasional, dimana pada tahapan ini menurut Piaget bahwa anak belajar menggunakan dan merepresentasikan objek dengan gambaran dan kata-kata. Artinya bahwa selain mengembangkan ketrampilan bahasanya, anak mulai mempresentasikan benda-benda dengan kata-kata dan gambar dan cenderung egosentris. Pada titik inilah peran orang tua termasuk guru untuk mengarahkan anak usia tersebut untuk lebih mengenal dengan lingkunga, termasuk membentuk perilaku anak untuk cinta lingkungan.

Hasil pengamatan yang dilakukan diperoleh pada saaat pelatihan ditemukan bahwa:

(1) Peserta sangat antusias mengikuti pelatihan dengan aktif dalam mengikuti setiap sesi pembuatan APE ecobrick.

(2) Peserta memiliki komitmen untuk mengikuti kegiatan pelatihan APE ecobrick dari awal hingga akhir

(3) Peserta memberikan tanggapan positif terhadap pelatihan APE ecobrick yang dianggap mencerahkan, karena selama ini pemanfaatan sampah paltik untuk APE ecobrick PAUD belum pernah dilakukan.

(4) Pemahaman guru tentang APE ecobrick sudah baik, dan kreatifitas para peserta juga sudah mulai ada, hal ini dilihat dari masing-masing peserta yang dapat membuat APE ecobrick dengan baik dan lancar sesaui dengan ide masing-masing peserta

Untuk melihat tingkat keberhasilan kegiatan pelatihan APE ecobrick bagi guru PAUD tersebut dilakukan, maka dilakukan evaluasi melalui lembar pengamatan dengan menggunakan 3 (tiga) indicator pengamatan, yakni; pengetahuan (knowledge), ketrampilan (skill) dan pemahaman (ability). Berdasarkan hasil evaluasi dari lembar pengamatan, diperoleh tingkat keberhasilan kegiatan pelatihan yang diuraikan sebagai berikut.

\section{1) Indikator Pengetahuan (Knowledge)}

Bahwa dalam pelaksanaan pelatihan yang diberikan kepada 20 orang peserta, tingkat pengetahuan peserta terkait dengan pemanfaatan sampah plastic sebagai alat permainan edukatitif (APE) ecobrick yakni 30 meningkat menjadi 70, atau mengalami kenaikan sebesar 42,86\%. Presentasi ini menunjukkan bahwa melalui pelatihan APE ecobrick para peserta telah mengetahui manfaat dan kegunaan dari sampah plastic tersebut, sehingga dapat dimanfaatkan untuk menjadi alat permainan edukatif. Selain itu pelatihan juga memberikan 
pemahaman kepada peserta bahwa APE ecobrick juga dapat membentuk karakter dan perilaku anak didik yang kenal dan cinta terhadap lingkungan.

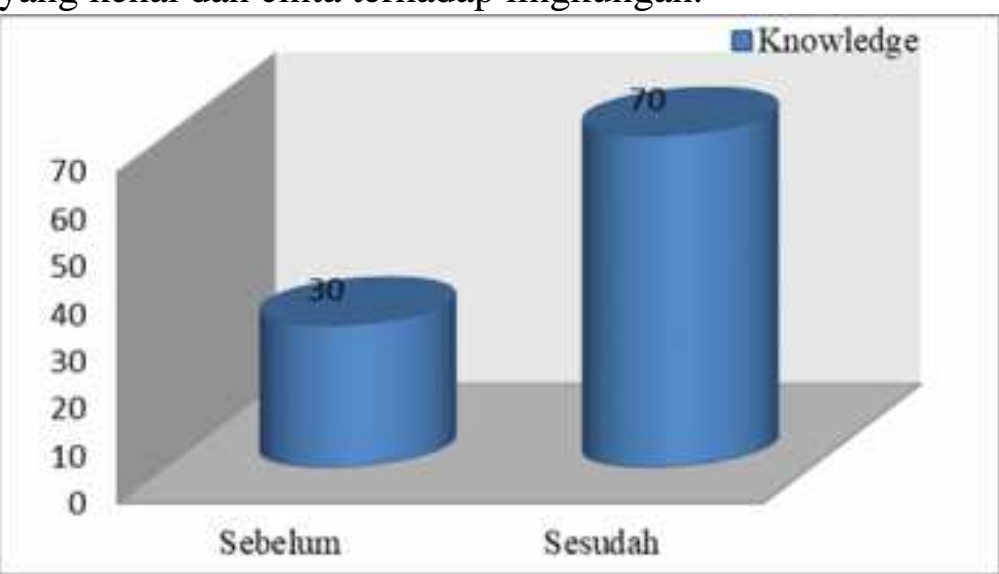

\section{Gambar 4. Grafik Capaian dari Indikator Pengetahuan (knowledge) pada Pelatihan APE Ecobrick}

\section{2) Indikator Ketrampilam (Skill)}

Untuk pencapaian pada indicator Ketrampilam (Skill) terkait dengan pelaksanaan pelatihan pemanfaatan sampah plastic sebagai alat permainan edukatitif (APE) ecobrick dari nilai sebelumnya 27 meningkat menjadi 61, atau mengalami kenaikan sebesar 44,26\%. Artinya bahwa pada skill pelatihan ini terjadi peningkatan yang signifikan, dimana para peserta dengan kemampuan yang dimilikinya dapat memanfaatkan sampah plastic menjadi alat permainan edukatif.

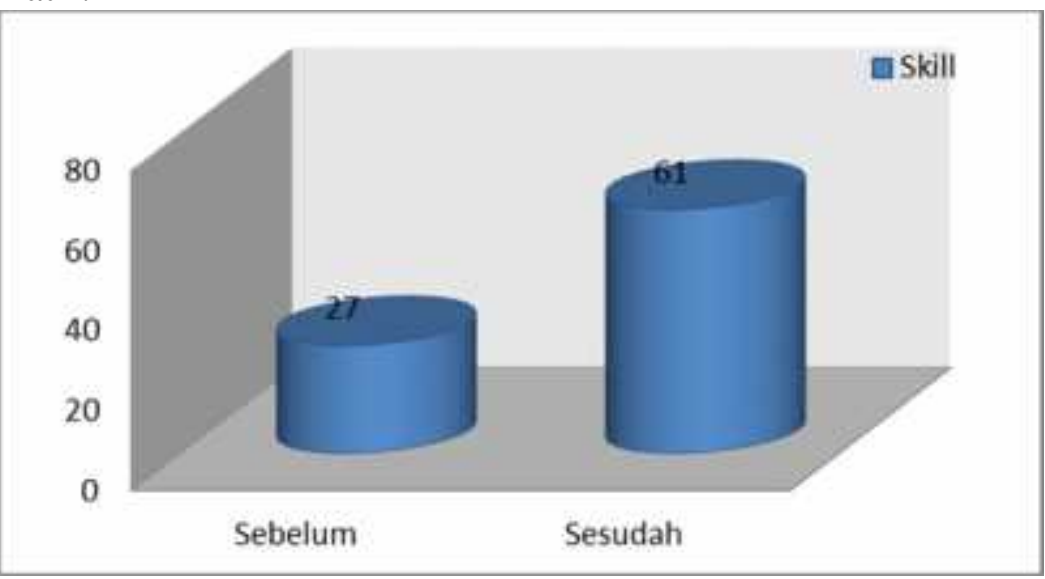

Gambar 5. Capaian dari Indikator Ketrampilan (Skill) pada Pelatihan APE Ecobreak

\section{3) Indikator Kemampuan (Ability)}

Untuk pencapaian indicator Kemampuan (Ability) pada pelaksanaan pelatihan pemanfaatan sampah plastic sebagai alat permainan edukatitif (APE) Ecobrick juga mengalami peningkatan yang signifikan. Berdasarkan pada pengukuran awal dari nilai sebelumnya 31 meningkat menjadi 70, atau mengalami kenaikan sebesar 44,29\%. Hasil ini tentunya memberi dampak positif terhadap peserta, dimana pelatihan ini dapat meningkatkan kemampuan para peserta dalam memanfaatkan sampah plastic menjadi alat permainan edukatif (APE Ecobrick) 


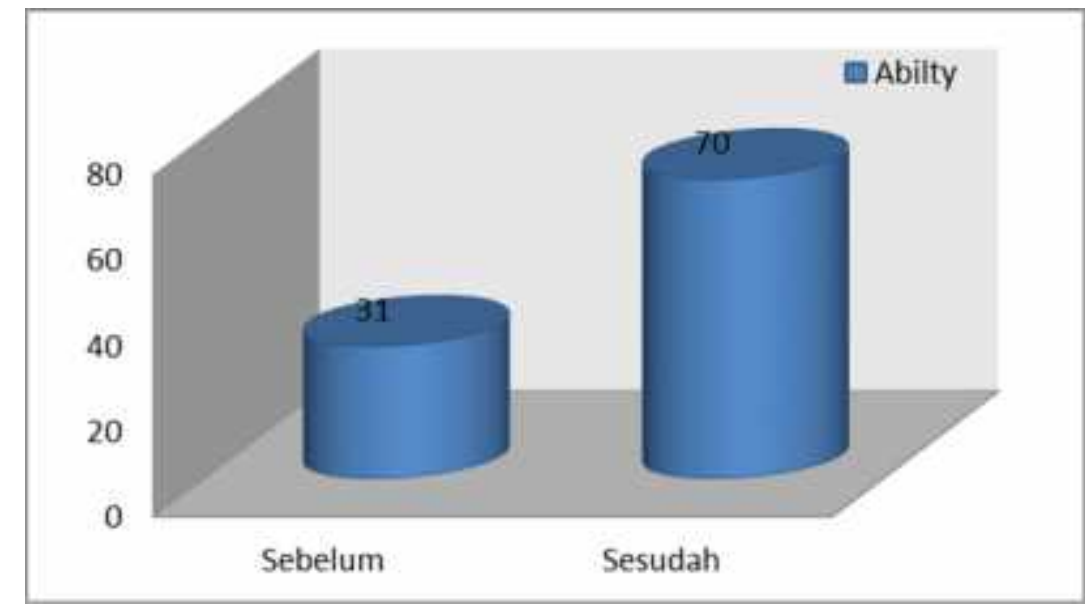

\section{Gambar 6. Grafik Capaian dari Indikator Kemampuan (Ability) pada Pelatihan APE Ecobrick}

Berdasarkan hasil evaluasi dari ketiga indicator di atas, baik aspek Pengetahuan (knowledge), Ketrampilam (Skill) dan Kemampuan (Ability) pada pelatihan APE ecobrick terutama pada saat kegiatan praktek atau produk ecobrick yang dibuat oleh peserta pelatihan secara individu dan telah disimulasikan, secara umum telah diperoleh hasil yang baik, dengan rata-rata peningkat sebesar $42 \%$ - 44\%. Presentasi kenaikan ini menunjukkan bahwa hasilnya sudah baik karena terdapat kenaikan pada masing-masing indicator.

Bahwa alat permainan adalah sumber belajar yang digunakan anak untuk memenuhi nalurinya. Alat permainan edukatif merupakan bagian yang tidak terpisahkan dalam pembelajaran anak. Ketersediaan alat permainan tersebut sangat menunjang terselenggaranya pembelajaran anak secara efektif dan menyenangkan sehingga anak-anak dapat mengembangkan berbagai potensi yang dimilikinya secara optimal (Adianti \& V.Ayuningtyas, 2020). Pemilihan alat permainan merupakan suatu kegiatan yang memerlukan bekal kemampuan yang memadai. Bekal kemampuan yang dimaksudkan adalah pengetahuan dan keterampilan bagaimana melakukannya sesuai dengan persyaratanpersyaratan tertentu sehingga alat permainan eduaktif yang dipilih betul-betul efektif dalam mengembangkan aspek-aspek perkembangan anak, terutama kaitannya dengan membentuk perilaku menjaga dan melestarikan lingkungan dengan memanfaatkan sampah platik yang banyak ditemukan akibat membuang sampah secara sembarang (Istirokhatun \& Nugraha, 2019).

Sampah sesungguhnya identik dengan estetika, sampah yang berserakan tentu saja mengganggu pandangan, menghasilkan bau busuk, mencemari dan merusak lingkungan dan mengancam ekosistem. Sampah yang banyak ditemukan adalah akibat dari buruknya perilaku manusia yang tidak peduli terhadap masa depan bumi. Untuk itu penting untuk membentuk perilaku anak didik, terutama untuk mencintai lingkungan. Kesadaran utama dalam menjaga dan melestarikan lingkungan dari sampah melalui edukasi sejak dini sangatlah diperlukan (Pujiati, 2019) (Chandra, 2020), maka demikian, peran guru sangat penting dalam membentuk karakter dan perilaku anak didik untuk memahami batapa pentingnya menjaga kualitas lingkungan, sehingga anak-anak perlu diperkenalkan sedini mungkin tentang bahaya sampah yang nantinya diharapkan akan lebih kreatif dan inovatif dalam mengubah sampah menjadi emas. 


\section{Kesimpulan}

Kesimpulan dari hasil pengabdian ini bahwa kegiatan pelatihan telah berdampak terhadap peserta yakni pada aspek pengetahuan (knowledge) adalah 42,86\%, ketrampilam (skill) adalah 44,26\% dan kemampuan (ability) adalah 44,29\%. Dengan demikian, kegiatan ini sangat membantu para guru dalam menghasilkan APE yang kreatif dan inovatif berbasis environmental approach, yang tentunya juga memperkenalkan kepada anak didik tentang bahaya sampah plastic terhadap lingkungan dan membentuk perilaku cinta lingkungan.

\section{Saran}

Adapun saran yang dapat disampaikan berdasarkan hasil kegiatan pengabdian ini antara lain adalah;

1) Perlu pembimbingan dan pendampingan lebih intensif, termasuk perlu adanya pengembangan APE yang lebih inovatif melalui kreatif guru dengan memanfaatkan media lingkungan sekitar, termasuk pembuatan APE dengan memanfaatkan teknologi informasi (IT).

2) Para guru PAUD harus lebih pro aktif, lebih kreatif dan inovatif dalam merancang dan membuat Alat Pendidikan Edukatif yang asyik dan menyenangkan. Terutama dalam memanfaatkan potensi wilayah Maluku Utara yang terdiri gugusan pulau, sehingga anak didik lebih didekatkan pada lingkungan alam yang menjadi masa depan bumi.

3) Kepada para penyelenggara pendidikan PAUD, para guru dan pihak terkait agar diharapkan dapat mengetahui jenis-jenis dan memahami pentingnya Alat Pendidikan Edukatif, Kreatif dan Inovatif. Terdapat berbagai alat permainan yang merupakan alat pendidikan yang edukatif bagi anak usia dini, namun para guru hendaknya bisa berkreasi dan berinovasi untuk merancang dan membuat alat-alat permainan sendiri untuk mengembangkan aspek-aspek perkembangan anak-anak PAUD.

\section{Daftar Pustaka}

Adianti, I. A., \& V.Ayuningtyas, N. (2020). Pelatihan Pembuatan Ecobrick kepada AnakAnak Siswa SD Kanisisus Kembaran, Bantul, Yogyakarta. Jurnal Ilmiah Padma Sri Kreshna, 2(1). https://doi.org/10.37631/psk.v2i1.121

Adnyani, L. D. S., Utami, I. A. M. I., Suprianti, G. A. P., Pratiwi, N. P. A., \& Wahyuni, L. G. E. (2019). Program Tabungan Ecobrick Desa Umeanyar. Senadimas, 446-454.

Akbar, Rengkung, M. M., \& Warouw, F. (2014). Analisis Sistem Persampahan di Kota Ternate. Jurnal PWK Universitas Sam Ratulangi, 6(3), 351-362.

Andriastuti, B. T., Teknik, J., Fakultas, L., Universitas, T., \& Tanjungpura, U. (2019). Potensi Ecobrick. Potensi Ecobrick Dalam Mengurangi Sampah Plastik Rumah Tangga Di Kecamatan Pontianak Barat, 07(2), 55-63.

Aulina, C. N., Rezania, V., \& Destiana, E. (2018). Pengabdian Kepada Masyarakat Melalui Pendampingan Bagi Guru Pos Paud. Jurnal ABDI, 3(2), 41. https://doi.org/10.26740/ja.v3n2.p41-45

Chandra, W. (2020). Ecobrick, Solusi Atasi Sampah Plastik selama Pandemi COVID-19. In Mongabay (Issue April). https://www.mongabay.co.id/2020/04/18/ecobrick-solusiatasi-sampah-plastik-selama-pandemi-covid-19/

Ela Patriana \& Nurismalatri, 2018. (2008). 少子化の要因 : 就業環境か価值観の変化かNo

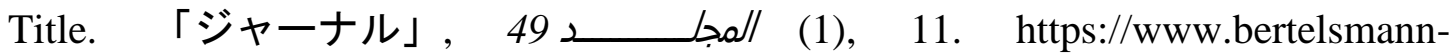
stiftung.de/fileadmin/files/BSt/Publikationen/GrauePublikationen/MT_Globalization_ 
Report_2018.pdf\%0Ahttp://eprints.lse.ac.uk/43447/1/India_globalisation\%2C society and inequalities\%281sero\%29.pdf\%0Ahttps://www.quora.com/What-is-the

Fitriani, S., \& Asih, H. M. (2019). Metode Full Costing Sebagai Dasar Penentuan Harga Produk Kreasi Sampah Ecobrick. Jurnal Integrasi Sistem Industri, 6(1), 65-69. http://jurnal.umj.ac.id/index.php/jisi\%0Ayang

Istirokhatun, T., \& Nugraha, W. D. (2019). Pelatihan Pembuatan Ecobricks sebagai Pengelolaan Sampah Plastik di Rt 01 Rw 05, Kelurahan Kramas, Kecamatan Tembalang, Semarang. Jurnal Pasopati "Pengabdian Masyarakat Dan Inovasi Pengembangan Teknologi,” 1(2), 85-90. https://ejournal2.undip.ac.id/index.php/pasopati/article/view/5549\%0Ahttps://ejournal 2.undip.ac.id/index.php/pasopati/article/download/5549/3111

Palupi, W., Wahyuningsih, S., Widiyastuti, E., Nurjanah, N. E., \& Pudyaningtyas, A. R. (2020). Pemanfaatan Ecobricks Sebagai Media Pembelajaran Untuk Anak Usia Dini. DEDIKASI: Community Service Reports, 2(1), 28-34. https://doi.org/10.20961/dedikasi.v2i1.37624

Pujiati, A. (2019). Gaya Hidup Minim Sampah Dan Ecobrick Alternatif Solusi. November, 890-895. https://doi.org/10.30998/simponi.v0i0.468 